\title{
Innowacje genderowe. Studium przypadku: Nauka. Genetyka różnicowania płciowego
}

\author{
Londa Schiebinger \\ Stanford University \\ Inés Sánchez de Madariaga \\ Technical University of Madrid \\ Przekład: Aleksandra Derra \\ Konsultacja merytoryczna: Milena Kulasek
}

\author{
Ineke Klinge \\ Maastricht University
}

Martina Schraudner

Technical University Berlin

(Tekst oryginalny pt. „The Genetics of Sex Determination: Rethinking Concepts and Theories” opublikowano w 2013 r. w Gendered Innovations in Science, Health \& Medicine, Engineering and Environment, URL = $<$ http://ec.europa.eu/research/gendered-innovations/>, 10.09.2014 ${ }^{10}$.)

Przekład zaakceptowano: czerwiec 2015; opublikowano: lato 2015.

\begin{abstract}
Abstrakt
Wyzwanie badawcze

Badania nad różnicowaniem płci biologicznej w przeszłości skupiały się przede wszystkim na rozwoju jąder, ignorując w dużym stopniu aktywne procesy, które kontrolują rozwój jajników (Veitia 2010). De facto przez bardzo długi czas uważano, że rozwój jajników „przebiega pod nieobecność innych czynników, domyślnie (default)” lub „pasywnie” w wyniku bipotencjalności gonad.

\section{Metoda: przemyślenie na nowo pojęć i teorii}

Przyjęcie, że rozwój tego, co żeńskie, przebiega „domyślnie”, sprawiło, że badania skupiały się na różnicowaniu jąder, a po odkryciu genu $S R Y$ na powiązanych z tym zagadnieniach, jak na przykład SOX9. Powstawanie jajników badano dużo rzadziej. Modele naukowe, które traktowały żeńską ścieżkę rozwojową jako „domyślną”, były niezgodne z brakiem rozwoju jajników w przypadku zespołu Turnera, by wymienić tylko jeden przykład.
\end{abstract}

\footnotetext{
${ }^{10}$ Przekład publikowany za zgodą właścicieli praw do tekstu. Tłumaczka bardzo dziękuje Milenie Kulasek za pomoc merytoryczną przy przekładaniu zawiłości terminologii genetycznej na język polski (przyp. red.).
} 


\section{Innowacje genderowe:}

1. Rozpoznanie, że różnicowanie się jajników jest procesem czynnym. Obecne badania wskazują na aktywne mechanizmy, które są niezbędne do wytworzenia jajników (Veitia 2010; Uhlenhaut i in. 2009). Odkrycia te zwiększyły naszą wiedzę na temat rozwoju jąder i tego, w jaki sposób ścieżki rozwoju jajników i jąder nawzajem na siebie oddziałują.

2. Odkrycie, że zachowanie [funkcjonujących normalnie] jajników i jąder jest procesem ciagłym. Badania nad rozwojem jajników pokazały, że gen kodujący regulator transkrypcji FOXL2 musi ulec ekspresji w dojrzałym pęcherzyku jajowym, aby zapobiec „przekształceniu dojrzałego jajnika w jądro” (Uhlenhaut i in. 2009). Następnie badacze odkryli, że czynnik transkrypcyjny DMRT1 jest potrzebny, by zapobiec przeprogramowaniu komórek Sertolego (podporowych komórek kanalika nasiennego) w warstwę ziarnistą (komórki wokół oocytu) (Matson i in. 2011).

3. Nowy język służący do opisu różnicowania się gonad. Badacze odrzucili ideę „tego, co domyślne” i podkreślają, że o ile ścieżki rozwoju samicy i samca są odmienne, o tyle formowanie jajników (podobnie jak jąder czy każdego innego organu) jest procesem czynnym. Każda z powyższych ścieżek rozwoju wymaga wystąpienia złożonej kaskady czynników genetycznych we właściwych dawkach i precyzyjnie określonym czasie.

Słowa kluczowe: genetyka; gonady; różnicowanie płciowe; innowacja genderowa; język opisu.

\section{Idea rozwoju samicy jako hormonalnie domyślna}

Gonada zarodkowa jest bipotencjalna, to znaczy normalnie „powstaną z niej jeden lub dwa morfologicznie i funkcjonalnie różne organy, jądro albo jajnik" (Capel i in. 2006). W 1947 roku Alfred Jost wykazał, że kiedy żeński (XX) i męski (XY) zarodek królika przed powstaniem płci biologicznej zostanie poddany gonadektomii w macicy, u wszystkich osobników rozwiną się żeńskie przewody płciowe i żeńskie genitalia zewnętrzne, niezależnie od kariotypu (Jost 1947). Uczeni postawili hipotezę, że jądra uruchamiają rozwój męski za pomocą hormonów jąder. Badania nad bydłem pokazały, że kiedy płody przeciwnej płci mają anastomozy w łożysku pozwalające na wymianę hormonów, płody XX podlegają maskulinizacji, ale płody XY się nie feminizują (Jost i in. 1972). W wyniku tych i innych badań ustalono, że pod nieobecność hormonów jąder powstanie zarodek żeński. 


\section{Rysunek 1}

Kariotyp człowieka w komórkach diploidalnych

Chromosomalnie kobiety są $46 \mathrm{XX}$, a mężczyźni $46 \mathrm{XY}$

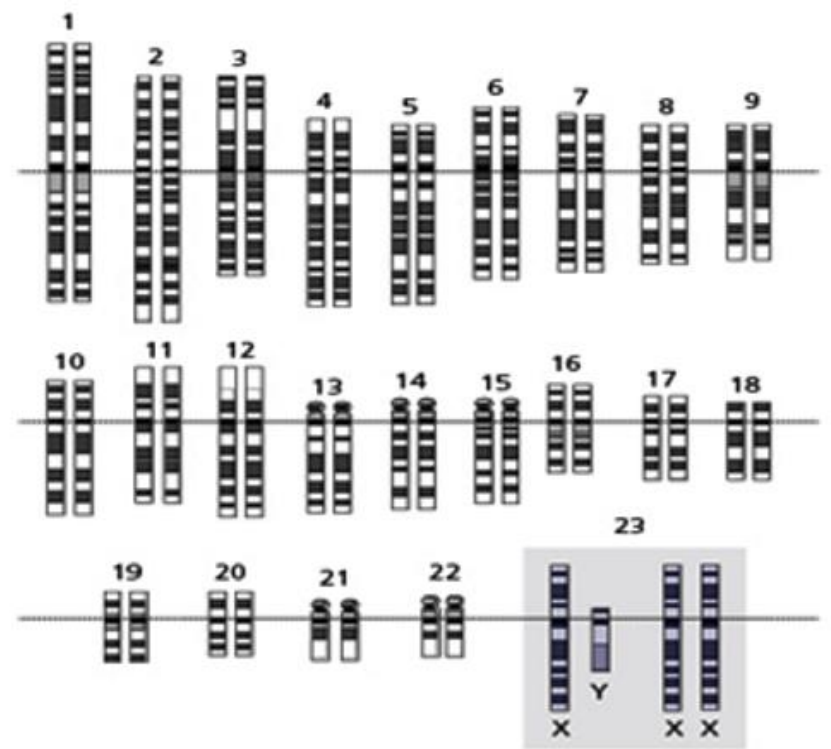

\section{Idea rozwoju samicy jako genetycznie domyślna}

Odkrycie przez Nettie Stevens i Edmunda Wilsona w 1905 roku chromosomu Y sprawiło, że zaczęto używać opisu XX/XY na określenie zróżnicowania płciowego, gdzie kobiety były XX, a mężczyźni XY (Stevens 1905; Wilson 1905). Początkowo nie było jasne, czy ludzką płeć biologiczną dookreśla ilość chromosomów X, czy obecność lub brak chromosomu Y. Kolejne badania nad zespołem Klinefeltera i zespołem Turnera $\mathrm{w}$ latach pięćdziesiątych XX wieku wykazały, że to obecność chromosomu Y determinuje płeć biologiczną u ludzi (Jacobs i in. 1959; Ford, 1959). Gdyby działo się to za sprawą obecności chromosomu X, pacjenci z zespołem Klinefeltera (47 XXY) powinni być kobiecy, ponieważ mają typowy zestaw dwóch X-ów, a pacjenci z zespołem Turnera (45 X0), powinni być męscy, ponieważ mają typową dla mężczyzn liczbę chromosomów X, czyli jeden. Jednak pierwsi mają fenotyp męski, a drudzy żeński. Obserwacje te doprowadziły do poszukiwań odpowiedzialnego za płeć biologiczną genu na chromosomie Y. W artykule Andrew Sinclaira i współpracowników z 1990 roku, który ukazał się w „Nature”, gen z chromosomu Y określono jako determinujący płeć biologiczną odcinek chromosomu Y (SexDetermining Region $Y$, w skrócie $S R Y$ ), podkreślając jednak, że prawdopodobnie wiele różnych genów potrzeba do ustalenia zarówno płci męskiej, jak i żeńskiej (Sinclair i in. 1990). Późniejsze badania potwierdziły, że u myszy XX rozwijają się jądra, jeśli podczas rozwoju embrionalnego wstrzyknie się im fragmenty DNA zawierające sekwencję genu SRY (Koopman i in. 1991). Bada- 
nia nad ludzkimi pacjentami rozpoznanymi jako mężczyźni (46 XX), u których $S R Y$ przemieścił się na chromosom X, dodatkowo potwierdzały, że SRY wystarcza do uruchomienia rozwoju osobnika męskiego (Berkovitz i in. 1992). $\mathrm{W}$ kolejnych latach badania skupiły się $\mathrm{w}$ dużym stopniu na problematyce związanej z SRY.

\section{Wyzwanie: idea tego, co domyślne i jej wpływ na ustalanie priorytetów badawczych}

W tym okresie badania nad różnicowaniem płci biologicznej skupiały się na problemie dotyczącym genetyki dookreślania męskich jąder (Richardson 2013). O żeńskim rozwoju płciowym sądzono, że odbywa się niejako „domyślnie”, pod nieobecność SRY. Angielskie słowo „default” znaczy „niepowodzenie w działaniu; zaniechanie” lub „z góry wybrana opcja (...), kiedy wybór nie został dookreślony" (Oxford English Dictionary, 2011). W przypadku różnicowania płci biologicznej dla żeńskiej ścieżki rozwojowej powszechnie przyjęto model „domyślny”. Zgodnie z nim jajnik powstaje w wyniku nieobecności jakiegoś innego działania, zatem nie badano rozwoju jajników. Podczas gdy większość grup badawczych dalej skupiała się na genetyce kształtowania się jąder jako kluczowej dla seksualnego rozwoju ssaków, niektórzy biologowie ewolucyjni protestowali przeciwko modelowi „domyślności”. Na przykład w 1986 roku Eva Eicher i Linda Washburn podważyły przekonanie o „powstawaniu tkanek jajnikowych jako zdarzeniu pasywnym, które dzieje się automatycznie”, przekonując, że ,jest to tak samo aktywny, genetycznie ukierunkowany proces rozwojowy jak powstawanie tkanek jąder, zresztą jak każdy proces różnicowania komórek”. Biolożki te zauważyły, że „prawie niczego nie napisano na temat powstawania tkanek jajnikowych z niezróżnicowanych gonad" (Eicher i in. 1986; zob. także Fausto-Sterling 1989).

\section{Innowacja genderowa pierwsza: rozpoznanie, że formowanie jajników jest procesem aktywnym}

W połowie lat dziewięćdziesiątych XX wieku biologowie rozwojowi rozpoznali, że „podczas gdy czynniki, jakie biorą udział w różnicowaniu płci męskiej zostały dobrze przebadane, ścieżka regulująca powstanie żeńskiej płci biologicznej pozostaje w dużej części niedookreślona” (zob. Biason-Lauber i in. 2008; Richardson 2013). Jednocześnie, dane zarówno z badań nad zwierzętami, jak i studiów nad ludzkimi pacjentami, pokazywały, że do dookreślania płci biologicznej potrzeba dużo więcej niż obecności lub braku SRY. Obserwacje te są następujące: 
1. Nieobecność SRY nie wystarcza do wykształcenia funkcjonującego jajnika; potrzebne są oba chromosomy X. To, że u kobiet (45 XO) z zespołem Turnera rozwijają się dysfunkcyjne jajniki, wskazuje, że dwa chromosomy X są niezbędne do tego, by odbywał się normalny rozwój osobnika żeńskiego (Bondy 2010). Ta dysfunkcja jest spowodowana utratą gamet w czasie rozwoju. Zdolne do życia gamety są potrzebne, by skonstruować funkcjonujący jajnik (Persani i in. 2009). Rozwój jąder różni się tutaj tym, że „funkcjonujące” (wydzielające hormon) jądro może rozwinąć się pod nieobecność gamet, jak w przypadku mężczyzn XX (Kim i in. 2010).

\section{Wrażliwe na małe dawki geny mogą uchylić rozwój osobnika mę- skiego nawet, kiedy SRY jest obecny.}

W 1994 roku badacze odkryli kobietę (46, XY) z nieuszkodzonym SRY i ustalili, że duplikacje specyficznego locus chromosomu X „wystarczają, by zakłócić normalny rozwój jąder przy obecności SRY" (Bardoni i in. 1994). W późniejszych badaniach gen, który bierze w tym udział nazwano $D A X 1$, a studia nad wspomnianą kobietą (46, XY) pokazały, że „duplikacje $D A X 1$ u osobników XY powodują odwrócenie rozwoju płciowego od męskiego do żeńskiego” (Ludbrook i in. 2004). DAX1 jako taki „może być genem działającym przeciw jądrom” (Sekido i in. 2009).

Ponowne skonceptualizowanie żeńskiej ścieżki rozwojowej jako „aktywnej” wprowadza ważną innowację genderową: Badacze zaczęli dookreślać konkretne mechanizmy, jakie muszą przebiegać, by wytworzyć i zachować [normalnie funkcjonujący] jajnik - podczas jego rozwoju, po urodzeniu, aż do dorosłości. Wyłoniło się kilku genetycznych kandydatów, włączając w to WNT4 oraz FOXL2. Badacze zrozumieli, że żeńska płeć biologiczna wymaga trwałego i ciągłego podtrzymywania w czasie dorosłości (zob. metoda). Niektóre geny, jak WNT4, są potrzebne do rozwinięcia właśnie żeńskiej płci biologicznej, a nie męskiej (Swain i in. 1998).

Obecne prace wskazują, że zarówno męska, jak i żeńska linia rozwoju opiera się na działaniach dominujących genów, gdzie $S R Y$ aktywnie wspiera męską ścieżkę poprzez zwiększenie ekspresji SOX9, podczas gdy $\beta$-katenina, Rspo1 i FOXL2 aktywnie wspierają ścieżkę żeńską przez represję SOX9. Stosowna ilość czasu (i poziom ekspresji) dookreślą, która z nich zwycięży (Sekido i in. 2008; Veitia 2010). Zob. poniższy rysunek. 


\section{Rysunek nr 2}

Zdarzenia molekularne i genetyczne w dookreślaniu płci biologicznej u ssaków Produkty genów w żeńskiej ścieżce rozwoju hamują ekspresję SOX9; produkty genów w męskiej ścieżce rozwoju stymulują jego ekspresję

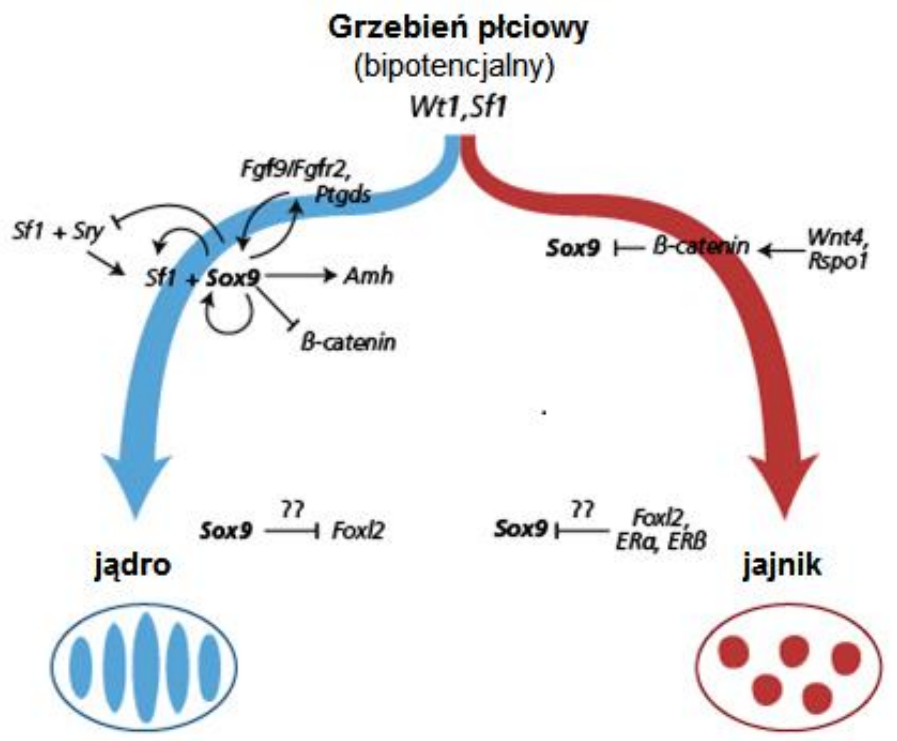

„Bipotencjalny grzebień płciowy ukształtowany zostaje przez geny, włączając w to Wt1 i $S f 1$, których wczesna ekspresja może także zainicjować ekspresję SOX9 u obu płci. $\beta$ katenina na tym etapie może kumulować się w odpowiedzi na sygnały Rspo1-Wrt4. W prekursorach komórek podstawnych zawierających XX ilość $\beta$-kateniny może podnieść się do poziomu, który wystarcza do represji $S O X 9$, albo za pomocą bezpośredniego oddziaływania białek, które prowadzi do obopólnego zniszczenia, co można zobaczyć w rozwoju chrząstek, albo w wyniku bezpośredniego wpływu na transkrypcję SOX9. Jednakże w prekursorach komórek podstawnych zawierających XY, zwiększający się poziom SF1 aktywuje ekspresję SRY i wtedy SRY razem z SF1 indukują ekspresję SOX9. Kiedy poziom SOX9 osiągnie wartość graniczną, zaczyna działać kilka pozytywnych pętli regulacyjnych, włączając w to autoregulację własnej ekspresji i formowanie się sprzężenia wprzód poprzez ścieżki sygnałowe FGF9 oraz PGD2. Jeśli aktywność SRY jest słaba, niska lub późna, nie udaje się mu wzmocnić ekspresji SOX9, zanim $\beta$ katenina osiągnie poziom, który wystarcza, by ten gen wyłączyć. Na późniejszych etapach [poziom białka] FOXL2 rośnie, co może pomóc, prawdopodobnie razem z ERs, podtrzymywać różnicowanie się warstwy ziarnistej poprzez hamowanie ekspresji SOX9. W jądrach SOX9 wspomaga ścieżkę ich rozwoju, włączając w to aktywację Amh, prawdopodobnie tłumi także działanie genów jajnikowych, włączając w to Wnt4 i FOXL2. Niemniej jakikolwiek mechanizm, który zwiększa ekspresję SOX9 w wystarczającym stopniu, spowoduje rozwój komórek Sertolego, nawet przy nieobecności SRY” (Sekido i in. 2009)

\section{Metoda: przemyślenie na nowo pojęć i teorii}

Teorie i pojęcia są jednym z czynników, które kształtują priorytety badawcze. W przypadku genetyki różnicowania płci biologicznej biologowie zawiedli, nie podważając „domyślnego” modelu rozwoju jajników odziedziczonego z lat pięćdziesiątych i sześćdziesiątych XX wieku. Pojęcie „pasywności” związanej z żeńskością i kobiecością odpowiada teoriom naukowym i założeniom na 
temat płci, jakie przyjmuje się obecnie szerzej w społeczeństwie (Schiebinger 1989; Richardson 2013). Ponowne przemyślenie teorii sprawiło, że postawiono nowe pytania na temat rozwoju jajników i pozwoliło odkryć całą kohortę genów, które są potrzebne do ich funkcjonowania. Spora ilość „eksperymentów z przesiewowymi badaniami genetycznymi pokazało, że wiele genów ulega ekspresji właśnie w jajniku” (Liu 2010).

\section{Innowacja genderowa druga: Odkrycie, że zachowanie [funkcjonujących normalnie] jajników $i$ jąder jest procesem ciągłym}

Dodatkowo poza studiami nad rozwojem jajników badacze starali się zrozumieć ich określone patologie. Biologowie zajmujący się genetyką zespołu o nazwie BPES (blepharophimosis / ptosis / epicanthus inversus syndrome, zespół zwężenia szpary powiekowej-opadania powiek - odwróconej zmarszczki nakątnej), który wiąże się z uszkodzeniem jajników, rozpoznali, że gen FOXL2 jest konieczny dla zachowania normalnie funkcjonujących jajników (Crisponi, 2001). Późniejsze badania wykazały, że u dorosłych FOXL2 jest niezbędny, by nieprzerwanie wyciszać $S O X 9$, a w ten sposób uniemożliwić komórkom pęcherzyków jajowych przekształcenie w komórki ,jądropodobne” (Uhlenhaut i in. 2009). Zob. diagram poniżej, przedrukowany z Uhlenhaut i in. 2009.

\section{Rysunek nr 3}

Model regulacji SOX9 potrzebny do zachowania płci biologicznej

Geny w żeńskiej ścieżce rozwoju powstrzymują działanie SOX9; geny w męskiej ścieżce rozwoju wywołują jego ekspresję

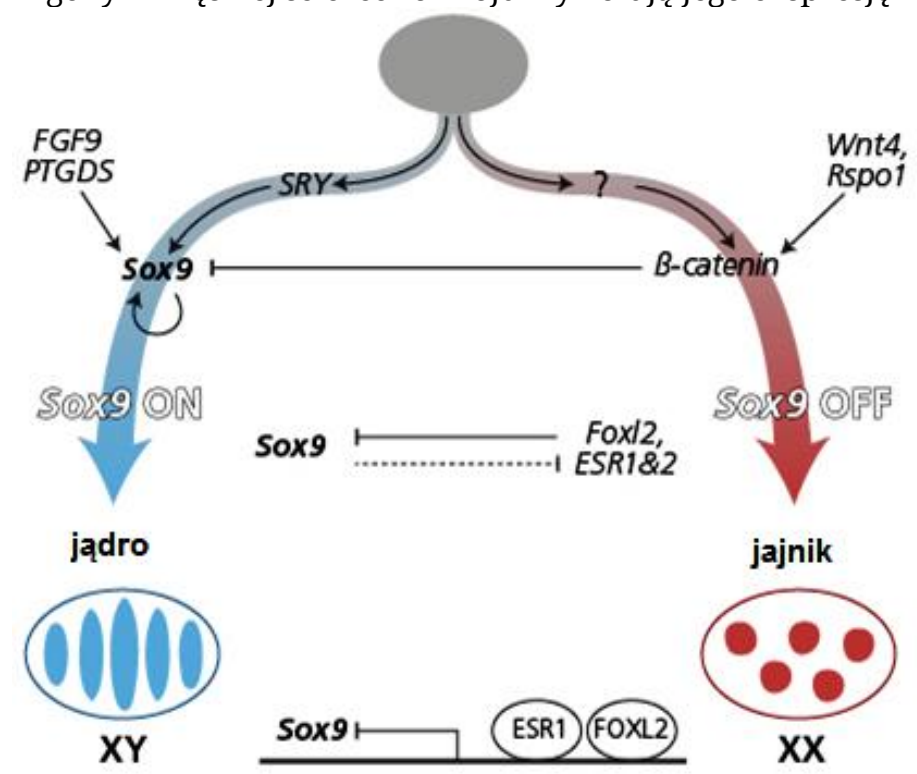

„Podczas wczesnych etapów różnicowania się płci biologicznej SRY zwiększa ekspresję SOX9, a dalsze pozytywne pętle autoregulacyjne, wraz z samym SOX9, ścieżką sygnałową FGF9 oraz 
prostaglandyny D2, aktywują i podtrzymują ekspresję SOX9 w gonadach męskich, podczas gdy $\beta$ katenina, stabilizowana przez działanie WNT4 i RSPO1, blokuje ekspresję SOX9 w gonadach żeńskich. Po porodzie aktywność $\beta$-kateniny się obniża, zatem w dojrzałych gonadach żeńskich potrzebne są FOXL2 i receptory estrogenu (ESR1/2) do represji SOX9, aby zagwarantować utrzymanie somatycznych komórek jajnikowych. Represja transkrypcyjna SOX9 za pomocą FOXL2 i receptorów estrogenu jest konieczna podczas całego życia kobiety, aby przeciwdziałać transdyferencjacji somatycznych komórek jajnikowych w jądrowe (PTGDS, syntaza prostaglandyny D)” (Uhlenhaut i in. 2009)

Podobnie jak w przypadku FOXL2, późniejsze eksperymenty pokazały, że „wyznaczenie męskiej płci biologicznej nie jest wyborem stałym, a Dmrt1 jest kluczowy, aby utrzymać funkcjonujące jądra” (Herpin i in. 2011). Podobnie jak utrata FOXL2 może spowodować przeprogramowanie warstwy ziarnistej (komórek wokół oocytu) w komórki Sertolego, utrata Dmrt1 może przeprogramować komórki Sertolego w warstwę ziarnistą. Dmrt1 wycisza pewne geny biorące udział w rozwoju jajników. Zob. diagram poniżej, przedrukowany z Matson i in. 2011.

\section{Rysunek nr 4}

Model regulacji utrzymania pourodzeniowej płci biologicznej za pomocą Dmrt1 Regulacja bezpośrednia oznaczona liniami ciągłymi, regulacja pośredna lub potencjalna - liniami przerywanymi

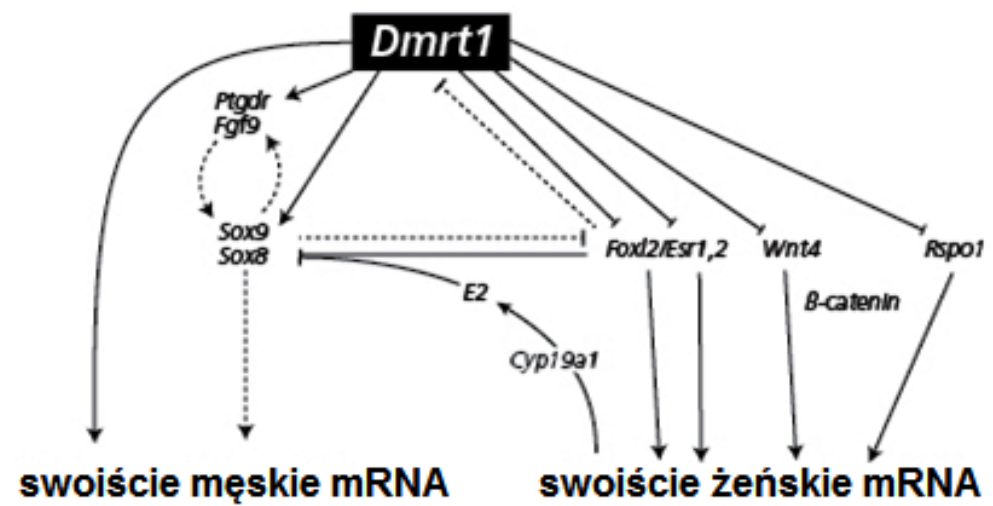

\section{Innowacja genderowa trzecia: nowy język do opisu różnicowania się go- nad}

Powstawania jajników nie postrzega się już jako procesu zachodzącego „domyślnie”: takiego, który przebiega pod nieobecność SRY i automatycznie prowadzi do rozwoju jajnika. Badacze opisują obie ścieżki rozwojowe jako aktywne, wymagające obecności złożonej kaskady wytworów genetycznych w odpowiednich dawkach i w stosownym czasie (zob. metoda). 


\section{Metoda: ponowne przemyślenie priorytetów badawczych i wyników ba- dań}

W opisywanym przypadku przemyślenie na nowo pojęć i teorii doprowadziło do przemyślenia priorytetów badawczych. W genetyce różnicowania płci biologicznej od lat czterdziestych po dziewięćdziesiąte XX wieku, badania skupiały się na wytwarzaniu tkanek jądrowych z niezróżnicowanych gonad, niewiele studiów prowadzono nad ścieżką rozwoju jajników. Chociaż wiele pytań pozostaje bez odpowiedzi, badacze rozpoznali teraz, że aby wytworzyć i utrzymać funkcjonujący jajnik, potrzeba wielu aktywnych mechanizmów. To $\mathrm{z}$ kolei doprowadziło do nowych badań nad utrzymaniem funkcji jąder.

\section{Wnioski}

Rozwój jajników nie jest, rzecz jasna, domyślną czy pasywną ścieżką rozwojową. Biologowie, genetycy i inni badacze rozpoznali, że zrozumienie rozwoju jajników jest kluczowe dla zrozumienia genetyki różnicowania płci biologicznej. Nowe badania nad aktywną ścieżką rozwojową jajników wprowadziły zmiany w języku, jakiego używa się do opisu różnicowania się płci biologicznej. Obecnie używany język uwypukla uzależnioną i konstruowaną przez geny naturę formowania się zarówno jajników, jak i jąder.

\section{Prace przywołane w tekście}

Bardoni, B., Zanaria, E., Guioli, S., Floridia, G., Worley, K., Tonini, G., Ferrante, E., Chiumello, G., McCabe, E., Fraccaro, M., Zuffardi, O., \& Camerino, G. 1994. A Dosage Sensitive Locus at Chromosome X021 is Involved in Male to Female Sex Reversal. Nature Genetics, 7 (4): 497-501.

Berkovitz, G., Fechner, P., Marcantonio, S., Bland, G., Stetten, G., Goodfellow, P., Smith, K., \& Migeon, C. 1992. The Role of the Sex-Determining Region of the Y Chromosome (SRY) in the Etiology of 46,XX True Hermaphroditism. Human Genetics, 88 (4): 411-416.

Biason-Lauber, A., \& Konrad, D. 2008. WNT4 and Sex Development. Sexual Development, 2 (4-5): 210-218.

Bondy, C. 2010. Turner Syndrome. In Carrell, D., \& Peterson, C., red. Reproductive Endocrinology and Infertility: Integrating Modern Clinical and Laboratory Practice: 307-324. New York: Springer Science and Business Media.

Brennan, J., \& Capel, B. 2004. One Tissue, Two Fates: Molecular Genetic Events that Underlie Testis versus Ovary Development. Nature Reviews Genetics, 5 (7): 509521.

Capel, B., \& Kim, Y. 2006. Balancing the Bipotential Gonad between Alternative Organ Fates: A New Perspective on an Old Problem. Developmental Dynamics, 235 (9): 2292-2300. 
Cotinot, C., Pailhoux, E., Jaubert, F., \& Fellous, M. 2002. Molecular Genetics of Sex Determination. Seminars in Reproductive Medicine, 20 (3): 157-168.

Crisponi, L., Deiana, M., Loi, A., Chiappe, F., Uda, M., Amati, P., Bisceglia, L., Zelante, L., Nagaraja, R., Porcu, S., Ristaldi, M., Marzella, R., Rocchi, M., Nicolino, M., Leinhardt-Roussie, A., Nivelon, A., Verloes, A., Schlessinger, D., Gasparini, P., Bonneau, D., Cao, A., \& Pilia, G. 2001. The Putative Forkhead Transcription Factor FOXL2 is Mutated in Blepharophimosis/Ptosis/Epicanthus Inversus Syndrome. Nature Genetics, 27 (2): 159-166.

DiNapoli, L., \& Capel, B. 2008. SRY and the Standoff in Sex Determination. Molecular Endocrinology, 22 (1): 1-9.

Eicher, E., \& Washburn, L. 1986. Genetic Control of Primary Sex Determination in Mice. Annual Review of Genetics, 20: 327-60.

Fausto-Sterling, A. 1989. Life in the XY Corral. Women's Studies International Forum, 12 (3): 319-331.

Ford, C., Miller, O., Polani, E., de Almeida, J., \& Briggs, J. 1959. A Sex Chromosome Anomaly in a Case of Gonadal Dysgenesis (Turner's Syndrome. Lancet, 1 (7075): 711-713.

Herpin, A., \& Schartl, M. 2011. Sex Determination: Switch and Suppress. Current Biology, 21 (17): R656-R659.

Jacobs, P., \& Strong, J. 1959. A Case of Human Intersexuality Having a Possible XXY SexDetermining Mechanism. Nature, 4657 (183): 302-303.

Jost, A. 1972. A New Look at the Mechanisms Controlling Sex Differentiation in Mammals. Johns Hopkins Medical Journal, 130 (1): 38-53.

Jost, A. 1970. Hormonal Factors in the Sex Differentiation of the Mammalian Foetus. Philosophical Transactions of the Royal Society of London, 259: 119-130.

Jost, A. 1947. Recherches sur la Différenciation Sexuelle de l'Embryon de Lapin. Archives d'Anatomie Microscopique et de Morphologie Expérimentale, 36: 271-315.

Kim, J., Bak, C., Chin, M., Cha, D., Yoon, T., \& Shim, S. 2010. SRY-Negative 46,XX Infertile Male with Leydig Cell Hyperplasia: Clinical, Cytogenetic, and Molecular Analysis and Review of the Literature. Fertility and Sterility, 94 (2): 753e5-753e9.

Koopman, P., Gubbay, J., Vivian, N., Goodfellow, P., \& Lovell-Badge, R. 1991. Male Development of Chromosomally Female Mice Transgenic for SRY. Nature, (351): 117121.

Liu, C. 2010. The Role of Beta-Catenin in the Development of Fetal Ovary and Female Germ Cells. Urbana-Champaign: Illinois Digital Environment for Access to Learning and Scholarship (IDEALS).

Loffler, K., Zarkower, D., \& Koopman, P. 2003. Etiology of Ovarian Failure in Blepharophimosis Ptosis Epicanthus Inversus Syndrome: Foxl2 Is a Conserved, Early-Acting Gene in Vertebrate Ovarian Development. Endocrinology, 144 (7): 3237-3243.

Ludbrook, L., \& Harley, V. 2004. Sex Determination: A 'Window' of DAX1 Activity. Trends in Endocrinology and Metabolism, 15 (3): 116-121. 
Matson, C., Murphy, M., Sarver, A., Griswold, M., Bardwell, V., \& Zarkower, D. 2011. DMTR1 Prevents Female Reprogramming in the Postnatal Mammalian Testis. Nature, 476 (7358): 101-105.

Oxford English Dictionary. 2011. Default (Noun.

Persani, L., Rossetti, R., Cacciatore, C. \& Bonomi, M. 2009. Primary Ovarian Insufficiency: X Chromosome Defects and Autoimmunity. Journal of Autoimmunity, 33 (1): 3541.

Richardson, S. 2013. Sex Itself: The Search for Male and Female in the Human Genome. Chicago: The University of Chicago Press.

Schiebinger, L. 1989. The Mind Has No Sex? Women in the Origins of Modern Science. Cambridge: Harvard University Press.

Schmidt, D., Ovitt, C., Anlag, K., Fehsenfeld, S., Gredsted, L., Treier, A., \& Treier, M. 2004. The Murine Winged-Helix Transcription Factor Foxl2 is Required for Granulosa Cell Differentiation and Ovary Maintenance. Development, 131 (4): 933-942.

Sekido, R., \& Lovell-Badge, R. 2009. Sex Determination and SRY: Down to a Wink and a Nudge? Trends in Genetics, 25 (1): 19-29.

Sekido, R., \& Lovell-Badge, R. 2008. Sex Determination Involves Synergistic Action of SRY and SF1 on a Specific Sox9 Enhancer. Nature, 453: 930-934.

Shaikh, M., Boyes, L., Kingston, H., Collins, R., Besley, G., Padmakumar, B., Ismayl, O., Hughes, I., Hall, C., Hellerud, C., Achermann, J., \& Clayton, P. 2007. Skewed X Inactivation is Associated with Phenotype in a Female with Adrenal Hypoplasia Congenita. Journal of Medical Genetics, 45 (9): 1-5.

Sinclair, A., Berta, P., Palmer, M., Hawkins, J., Griffiths, B., Smith, M., Foster, J., Frischauf, A., Lovell-Badge, R., \& Goodfellow, P. 1990. A Gene from the Human SexDetermining Region Encodes a Protein with Homology to a Conserved DNABinding Motif. Nature, 346: 240-245.

Stevens, N. 1905. A Study of the Germ Cells of Aphis Rosae and Aphis Oenotherae. Journal of Experimental Zoology, 2 (3): 313-333.

Swain, A., Narvaez, V., Burgoyne, P., Camerino, G., \& Lovell-Badge, R. 1998. Dax1 Antagonizes Sry Action in Mammalian Sex Determination. Nature, 391 (6669): 761767.

Tannour-Louet, M., Han, S., Corbett, S., Louet, J., Yatsenko, S., Meyers, L., Shaw, C., Kang, S., Cheung, S., \& Lamb, D. 2010. Identification of De Novo Copy Number Variants Associated with Human Disorders of Sexual Development. Public Library of Science (PLOS) Biology, 5 (10), e15392: 1-13.

Turnbull, C., Rapley, E., Seal, S., Pernet, D., Renwick, A., Hughes, D., Ricketts, M., Linger, R., Nsengimana, J., Deloukas, P., Huddart, R., Bishop, D., Easton, S., Stratton, M., Rahman, N., \& The United Kingdom Testicular Cancer Collaboration (2010. Variants near DMRT1, TERT, and ATF7IP are Associated with Testicular Germ Cell Cancer. Nature Genetics, 42 (7): 604-607. 
Uhlenhaut, N., Jakob, S., Anlag, K., Eisenberger, T., Sekido, R., Kress, J., Treier, A., Klugmann, C., Klasen, C., Holter, N., Riethmacher, D., Schütz, G., Cooney, A., LovellBadge, R., \& Treier, M. 2009. Somatic Sex Reprogramming of Adult Ovaries to Testes by FOXL2 Ablation. Cell, 139 (6): 1130-1142.

Veitia, R. 2010. FOXL2 Versus SOX9: A Lifelong "Battle of the Sexes.” BioEssays, 32 (5): 375-380.

Vilain, E. 2009. X-Linked Adrenal Hypoplasia Congenita. In Pagon, R., Dolan, C., \& Stephens, K., red. Gene Reviews. Seattle: University of Washington Press.

Welt, C. 2007. Primary Ovarian Insufficiency: A More Accurate Term for Premature Ovarian Failure. Clinical Endocrinology, 68 (4): 499-509.

Wilson, E. 1905. The Chromosomes in Relation to the Determination of Sex in Insects. Science, 22 (564): 500-502.

\begin{abstract}
The Challenge

Research into sex determination formerly focused primarily on testis development, while active processes controlling ovarian development were largely ignored (Veitia, 2010). In fact, ovarian development had long been considered a "default" or "passive" developmental outcome of the bipotential gonad.
\end{abstract}

\title{
Method: Rethinking Concepts and Theories
}

The notion of a "default" female pathway focused research on testis differentiation, and, after the discovery of Sry, on the downstream targets of Sry, e.g. Sox9. In contrast, the ovarian pathway was explored less. Scientific models portraying the female developmental pathway as a "default" were inconsistent with lack of ovarian development in Turner's syndrome, among other issues.

\section{Gendered Innovations:}

1. Recognition of Ovarian Determination as an Active Process. Current research is identifying the active mechanisms required to produce an ovary (Veitia, 2010; Uhlenhaut et al., 2009). These investigations have enhanced knowledge about testis development and how the ovarian and testicular pathways interact.

2. Discovery of Ongoing Ovarian and Testis Maintenance. Research into the ovarian pathway revealed that the transcriptional regulator FOXL2 must be expressed in adult ovarian follicles to prevent "transdifferentiation of an adult ovary to a testis" (Uhlenhaut et al., 2009). Subsequently, researchers found that the transcription factor DMRT1 is needed to prevent reprogramming of testicular Sertoli cells into granulosa cells (Matson et al., 2011).

3. New language to Describe Gonadal Differentiation. Researchers have dismissed the concept of "default" and emphasize that, while female and male 
developmental pathways are divergent, the construction of an ovary (like the construction of a testis or any other organ) is an active process. Each pathway requires complex cascades of gene products in proper dosages and at precise times.

Keywords: genetics; gonads; sex determination; gendered innovation; language to describe. 